\title{
Bio-Energy Production from Rice Straw a Review
}

\author{
Hassan Al-Haj Ibrahim* \\ Al-Baath University, Syria \\ Submission: May 29, 2018; Published: August 06, 2018 \\ *Corresponding author: Hassan Al-Haj Ibrahim, Al-Baath University, Homs, Syria, Email: sanjim84@yahoo.com
}

\begin{abstract}
Rice straw is an attractive lignocellulosic material that can be used for the production of liquid or gaseous fuel oils such as bio ethanol and biogas or methane by fermentation or other gasification processes. In addition, rice straw may also be considered for the production of bio hydrogen, where the straw is converted to bio-oil by fast pyrolysis and the bio-oil steam reformed for the production of hydrogen. Finally, rice straw can be made into a solid fuel that can be fired directly or after torrefaction or other processing
\end{abstract}

Keywords: Fossil fuel; Energy; Agricultural waste products; Crop production; Rice straw; Barley straw, Wheat straw; Renewable energy resources

\section{Introduction}

In this age characterized by energy scarcity and rising fossil fuel prices, renewable sources of energy have to be found in order to meet the continuously rising demand and decreasing energy reserves. Of such renewable sources of energy, agricultural waste products and other sources of biomass can no longer be neglected. In fact, agricultural waste has been one of the main features of crop production. Needless to say, uses for the waste products of agriculture other than energy production have been suggested, for example the systematic conversion of agriculture waste into humus or the conversion of straw into a substance having the properties of stable manure. Furthermore, adsorbents made of rice straw, barley straw, wheat straw, loess and charcoal can be used for water treatment and the used adsorbent reused after re-treatment as a fuel or fertilizer [1]. These and similar uses will not, however, be dealt with in this article.

Rice is one of the major foods, with consumption per capita of $65 \mathrm{~kg}$ per year, accounting for $20 \%$ of global ingested calories. Rice production is expected to increase significantly in the near future to feed the rising human population. Today, paddy rice culture produces 660 million tons of rice, along with 800 million dry tons of agricultural residues [2], mainly straw, a fact which makes rice straw one of the most abundant agricultural byproducts available in large quantities.

Rice straw may be managed through soil incorporation strategies but stubble and straw incorporation into wet soil during land preparation is associated with enhanced methane emissions. In many rice producing countries, on the other hand, burning the straw with consequent atmospheric pollution has been for a long time the only means of disposing of this potentially valuable waste by product [2], which can, if utilized efficiently, provide appropriate feedstock for competitive energy production. Rice straw may also be mixed with other straws and ligneous and waste materials such as paper mulberry, sawdust and livestock excretions in order to provide biomass material suitable for energy production. In rice producing countries such as Egypt, China and Korea rice straw is potentially one of the main renewable energy resources.

Straw is a lignocellulosic material consisting predominantly of celluloses and hemi-celluloses (60 percent or more) in addition to lignins (15 to 20 percent), water-soluble substances (5 to 12 percent), mineral matter or ash and proteins which are usually present in very small amounts ( 2.2 to 3.0 percent). The utilization of rice straw for energy production includes the production of liquid, gaseous and solid fuels.

\section{Bio-Liquid Fuel Production from Straw}

Of the liquid fuels that may be produced from rice straw through liquid fermentation, bio ethanol fuel with its high oxygen content and octane no. is most important, but other compounds may also be advantageously produced from rice straw such as biobutanol and butanediol glycol. Rice straw is an especially attractive material for bio ethanol production although several challenges and limitations occur in the process of converting it to ethanol due to its high ash and silica content.

The processes involved in bio ethanol production after an appropriate pre-treatment include hydrolysis of the straw to obtain hydrolyzate, followed by anaerobic fermentation. The 
selection of an appropriate pre-treatment technique is one of the major challenges in developing technologies for bio ethanol production from straw. The choice of pre-treatment methods plays an important role to increase the efficiency of enzymic digestibility and enzymic saccharification of the straw thereby making the whole process economically viable [3].

After separation of unwanted leaf and stem and drying, the straw is cut or pulverized and screened to obtain straw powder $[4,5]$. Alternatively, the straw may be pressed to obtain straw bricks, irradiated with $6 \mathrm{Co}-\gamma$ ray or electron beam accelerator, and finally pulverized and sieved [6].

For pre-treatment, the straw may be subjected to acid treatment, alkali treatment or hot water treatment $[4,7]$. By acidcatalyzed steam explosion or acid pre-treatment, hemicelluloses can be effectively removed from the straw, providing high yields of fermentable sugars. The yields of mono saccharides produced by enzymic hydrolysis of the straw pre-treated by these two pretreatment methods were found to be 46 and $42 \mathrm{~g} / \mathrm{l}$ respectively. Pre-treatment by ammonium fibre explosion, on the other hand, is distinctly different from other pre-treatment methods in that it does not significantly solubilise hemicelluloses. The yield of monosaccharides produced by enzymic hydrolysis of the pretreated straw in this case was found to be $37 \mathrm{~g} / \mathrm{l}$ [8].

The cellulose content of the straw can be increased by a liquefying process in which a mixture of straw powders including rice, corn and wheat straw powders is mixed with a phenol compound such as phenol, o-cresol, m-cresol, o-chlorophenol, o-nitrophenol, resorcinol, hydroquinone or polyethylene glycol. The resulting mixture is then subjected to a treatment involving heating, adding an organic or inorganic acid catalyst such as hydrochloric acid, nitric acid, sulphuric acid, phosphoric acid or benzene sulphonic acid, oxalic acid, acrylic acid, salicylic acid, formic acid and acetic acid, washing with an organic solvent, neutralizing, filtering and drying to obtain finally a solid with increased cellulose content [9].

Enzymes may be generated by adding glucose, $\mathrm{NH} 4 \mathrm{Cl}$ and water to the dry straw powder, sterilizing at $121{ }^{\circ} \mathrm{C}$ for $2 \mathrm{~h}$, inoculating 5\% Phanerochete chrysosporium into a specific medium, and culturing at $37-39{ }^{\circ} \mathrm{C}$ for 30 days. The generated enzymes including xylanase, $\mathrm{Mn}$-dependent peroxides and laccase are able to degrade xylogen [10].

After pre-treatment the straw is saccharified with the addition of an appropriately selected enzyme [4]. Straw powder may be saccharified with cellulase and xylanase. Trichoderma viride cellulase was used in one process for the degradation of straw [6]. Treatment of the straw powder with Phanerochaete chrysosporium by solid state culture and liquid state crude enzymes is also carried out in order to achieve lignin degradation [5].
Saccharification of rice straw for making bio ethanol may also be achieved without the use of chemicals such as acids or alkalis. The harvested rice straw is pulverized and saccharified with amyloglucosidase and $\beta$-glucan degrading enzyme. The rice straw may be heated to prevent degradation of the carbohydrates by microorganisms [11]. The final process in the production of ethanol is the fermentation of the saccharified liquid. This may be done using Pachysolen tannophilus $[5,10]$ or Saccharomyces cerevisiae and Pichia [6].

Experimental results demonstrated that initial xylose concentration and the establishment of adequate conditions of aeration are of great relevance to improve the ethanol production from xylose by Pichia stipitis, using rice straw hemicellulosic hydrolyzate as fermentation medium [12].

An enhanced inhibitor-tolerant strain of Pichia stipitis was successfully developed by researchers at the Institute of Nuclear Energy Research in Taiwan through adaptation to acid-treated rice straw hydrolyzate. The ethanol production obtained by the fermentation of $\mathrm{NaOH}$-neutralized hydrolyzate without detoxification using the adapted P. stipitis was comparable to the fermentation of overliming-detoxified hydrolyzate. The ethanol yield using the adapted P. stipitis with both types of hydrolyzate achieved about $87 \%$ of the maximum possible ethanol conversion. Furthermore, the newly adapted P. stipitis demonstrated significantly enhanced tolerance to sulphate and furfural despite the fact that both inhibitors had not been removed from the hydrolyzate by $\mathrm{NaOH}$ neutralization [13]. Besides bio ethanol, other compounds may be produced from rice straw through liquid fermentation.

To obtain 2,3-butanediol glycol the straw is processed through alkalization, liquefaction, or alkalization and steaming to obtain cellulose material having a cellulose content of 60 $71 \%$. After pulverization, enzymolysis is performed at $35-45^{\circ} \mathrm{C}$ followed by liquid fermentation [14].

Finally rice straw may be liquefied in sub- and supercritical solvent-water mixture in an autoclave. When 1,4-dioxanewater mixture is used at a temperature of $260-340{ }^{\circ} \mathrm{C}$, the tubular structure of lignocelluloses is decomposed with the occurrence of deoxygenation and decarboxylation reactions. Oil, preasphaltene and asphaltene fractions are the main products of the process whose yields and compositions are greatly affected by the volumetric ratio of 1,4-dioxane. It was shown that the nucleophilic and hydrolytic functions of water might be weaker at the higher ratio of 1,4-dioxane runs, resulting in lower amounts of phenolic, acidic, hydrocarbon and ester derivatives in the oil and the other fractions [15]. Using a mixed solvent (ethanol-water and 2-propanol-water mixture), the liquefaction of rice straw yielded primarily ester derivatives and the oxygen content in the bio-oil was decreased with the increase of the 
ratio of hydrogen donor solvent (ethanol and 2-propanol). The use of the solvent mixture may have inhibited the formation of low-boiling point materials [16].

\section{Biogas Production from Straw}

Anaerobic digestion may be used for the production of biogas from straws, where pre-treatment methods, as was pointed out earlier, have significant effects on the digestibility of straw. For developing industrialized biogas and bio-hydrogen-producing systems from biomass, combination of aerobic Bacillus and anaerobic Clostridium may play key roles [17].

In a process developed by Z. Lei et al. [18] rice straw particles were directly used as substrate for anaerobic digestion with acclimated sludge under room temperature and different levels of phosphate, where two biogas production peaks were observed. A two-stage first-order kinetic model was developed in this study and showed a good fit to the experimental data. It was found that an adequate level of phosphate addition could accelerate the biogasification process.

Using ammonia as a supplemental nitrogen source, rice straw may be converted into biogas by a high-rate anaerobic digestion system. A combination of grinding, heating at $110{ }^{\circ} \mathrm{C}$, and ammonia treatment resulted in the highest biogas yield, which is $17.5 \%$ higher than the yield of untreated straw [19]. Sodium hydroxide pre-treatment may be an efficient method for enhanced biogas production from straw.

In one process, rice straw was first pre-treated by $\mathrm{NaOH}$ in solid-state conditions and then an aerobically digested. Considerable fractions of hemicelluloses (36.8\%), cellulose (16.4\%), and lignin (28.4\%) were converted to relatively readily biodegradable substances while water-soluble substances were increased by $122.5 \%$. The crystallinity of cellulose was found to increase after the hydroxide treatment and the original three-dimensional network structure of lignin with a large molecular weight was changed into a linear structure with a small molecular weight. The ester bonds of lignin-carbohydrate complexes were destroyed through the hydrolysis reaction, releasing more cellulose for biogas production. The results obtained showed that the sugar content was doubled as a result of the hydroxide treatment and biogas yields were increased by up to $65 \%$ compared to the untreated rice straw $[20,21]$.

In another process straws were pulverized and mixed homogeneously with sodium hydroxide, sodium sulphide, and water and stored at normal temperature for 30 days; after which ammonium chloride and sodium hydroxide or hydrochloric acid solution was added and anaerobic digestion performed. An absorbent solution was used to remove carbon dioxide and hydrogen sulphide from the produced gas. Finally, the gas was passed through an active carbon molecular sieve to remove impurities and water [22]. Rice straw may also be gasified to produce methane or biogas containing $\mathrm{CO}, \mathrm{H} 2, \mathrm{CH} 4$ and tar (CnHm) [23], or it may be carbonized to produce a fuel gas and a carbonized semi-coke product which is processed into charcoal briquettes by the addition of a water-soluble polymer binder by mechanical pressing [24].

The pyrolysis mechanism of rice straw was investigated by Fu et. al. using a tube reactor with Fourier transform IR spectroscopy and thermo gravimetric analyzer. The results show that the maximum pyrolysis rate increases with increasing heating rate and temperature. The main pyrolysis gas products include $\mathrm{H} 2 \mathrm{O}, \mathrm{CO} 2, \mathrm{CO}, \mathrm{CH} 4, \mathrm{HCHO}$ (formaldehyde), $\mathrm{HCOOH}$ (formic acid), $\mathrm{CH} 3 \mathrm{OH}$ (methanol) and $\mathrm{C} 6 \mathrm{H} 5 \mathrm{OH}$ (phenol), with maximum release of $\mathrm{H} 2 \mathrm{O}, \mathrm{CO} 2, \mathrm{CO}$ and $\mathrm{CH} 4$ at $220-400{ }^{\circ} \mathrm{C}$. At about $350{ }^{\circ} \mathrm{C}$ aromatization starts and continues to increase at higher temperatures while the amounts of ether groups decrease [25].

The produced biogas is washed with water to remove dust and tar, dried and desulphurized using an appropriate chemical agent to remove sulphides [23], or the gas may be purified with $\mathrm{NaOH}$ solution to remove CO2, H2S, NO and H2O [26]. The strawderived tar can be used in the manufacture of pesticides or

pesticide additives, fertilizers, and disinfectants and deodorants for livestock [23].

Tar emission during gasification varies depending on temperature, residence time and other operating parameters. When gasification was carried out in a single stage reactor the maximum tar yields for rice straw was $25 \%$. In accordance with results obtained by Chen et al., tar emission can be reduced to low levels if gasification is carried out in a two-stage reactor using optimized operating conditions, but complete tar removal is difficult to realize [27]. Straw has also been considered for the production of biohydrogen.

In a study by Huang et al. it was suggested that a hydrogen rich fuel gas (51-55\% H2) can be produced from rice straw using microwave-induced pyrolysis. It was further suggested that focussed heating by microwaves made the resulting pyrolysis different from the traditional pyrolysis. The major components in the gaseous product were $\mathrm{H} 2, \mathrm{CO} 2, \mathrm{CO}, \mathrm{CH} 4$. Alkanes, polars, and low-ringed polycyclic aromatic hydrocarbons were three primary kinds of compounds in the liquid product. From the viewpoint of energy consumption, close to $60 \%$ of the input energy could be derived and utilized as bioenergy [28,29].

\section{Solid Fuel Production from Straw}

Rice straw can be used as a solid fuel of high calorific value or it may be converted into coke-like biomass or charcoal fuel. It may be used either separately or mixed with other biomass or waste products. Particles of rice straw processed by sodium hydroxide could also be used as binder in biomass fuel [30].

Rice straw may either be used directly in the form of bales, or processed by heating, pressing, compression-moulding or torrefaction to form high-density pellets which allows for the feedstock to be transported over longer distances. Straw pellets 
can be directly co-fired with coal or natural gas at very high rates and make use of the processing infrastructures at existing coal and gas plants. Rice straw pellets may be manufactured by moisturizing cut rice straw with water and extruding the moisturized straw through dies, wherein the amounts of water and extrusion pressure are controlled [31].

Solid fuel briquettes may be made from rice straw by a method comprising crushing and compression, where a pistonmold process may be used for compression. The controlling factors in this process which greatly affect the compressive strength of the briquettes include the size distribution of the crushed straw and the pressing temperature. It was found that mixing a certain percentage of a binder such as rice bran, soybean residue and sawdust (of for ex. Acacia confuse) or other biomass waste with the crushed rice straw increases the calorific value of the briquettes and decreases the energy required for compression. The effects of the binder are related to its type and percentage ratio $[32,33]$.

Powder mixtures of rice straw (especially Oryza sativa) bamboo or wood sawdust with calcium compounds (e.g. Ca $(\mathrm{OH}) 2$ ) may be used for the production of straw briquettes by extrusion of the mixture through rollers. The briquettes are suitable for combusting in a boiler with reduced noxious emissions, and the boiler flue gases are treated in an adsorption tower to remove $\mathrm{NOx}, \mathrm{SOx}$ and dust, and the resulting gases containing $\mathrm{CO} 2$ are then utilized in photosynthesis for the plant growth [34].

Different straws such as wheat, corn, sorghum and tobacco straws may be mixed with rice straw and other combustible wastes such as wood chips and herbal residues, or crop processing residues (peanut shell, rice hull, bagasse) and the resulting mixture used for the production of fuel rods or blockshaped fuel through a process of crushing or pulverizing, ovendrying, screening, compressing, and moulding or extruding. An additive containing a clay component (aluminium silicate) may be added before extrusion moulding. The compressed fuel rods have the advantages of long combustion time, high calorific value $(3,800 \mathrm{kcal} / \mathrm{kg})$, low cost, and little pollution. They can be used for combustion directly in boilers and power generation or they may be used in the production of charcoal. The ashes generated in the combustion of the fuel rods can be used as fertilizer [3538].

One of the problems associated with the combustion of rice straw and other herbaceous materials is ash content which may cause extensive slagging, deposition and bed agglomeration during fluidized bed combustion. Large-sized ash particles may act as the necks in the formation of agglomerates and smallsized ash particles may contribute to bed defluidization [39]. In grate firing, higher ash content adversely affects the combustion stability [40].

It was found by examining bed materials from fluidized bed combustion of wood and rice straw fuel blends that melting of locally accumulated dust or aerosol mixture of ash particles and mullite led to the accumulation of liquid droplets, preferentially on surfaces and contact areas between bed particles sheltered from turbulence and mechanical interaction, and these formed thin discontinuous films of adhesive cement by filling of irregularities on individual and partially agglomerated bed particle surfaces. As a result of this film formation the bed particles were locally enlarged and this led ultimately to bed agglomeration. Large straw ash particles appear to have mostly been passively incorporated into the adhesive melt without melting or reaction [41].

Examination of straw particles indicate that a narrow continuous surface zone borders virtually all straw particles where high concentrations of alkali metals such as potassium and sodium and other elements are found. It was shown, in a study in which a scanning electron microscope coupled with energy-dispersive spectroscopy is used, that such alkali metals melt as a result of high combustion temperatures and coat the surface of ash particles making them sticky with a tendency to adhere to the surface of bed particles, thus contributing to bed defluidization $[39,41]$.

In order to reduce the ash content, and chlorine and nitrogen content, and increase the calorific value of rice straw, cut rice straw is added to different acid solutions and heated in a reactor filled with activated carbon to $25-100{ }^{\circ} \mathrm{C}$ for $1-24 \mathrm{~h}$, filtered and dried. The acids that can be used include hydrofluoric acid, acetic acid or a mixed solution of acetic and anhydrous citric acids. The treated rice straw can be mixed with an adhesive selected from starch, paraffin wax, molasses, vegetable oil, vegetable fatty acid, and lignin sulphate, extruded for 3-30min to form a solid fuel of calorific value greater than $4,300 \mathrm{kcal} / \mathrm{kg}$, an apparent density larger than $500 \mathrm{~kg} / \mathrm{m} 3$, ash content less than 0.7 , and chlorine and nitrogen contents less than $0.05 \%$ and $0.03 \%$ respectively [42].

To solve slagging problems of straw briquettes that may occur during combustion and increase the combustion efficiency, the addition of an antislagging additive composed of magnesium carbonate, aluminium oxide and calcium carbonate has been suggested [43]. To inhibit agglomeration of straws on burning or gasification in power plants and industrial boilers, a swirlingflow air distribution apparatus may be used for forming swirling flow at the bottom of the fluidized bed [44].

Leaching of the inorganic constituents from straws offers also an approach to avoid extensive ash slagging and agglomeration. Leaching occurs naturally in the field when straw is exposed to rainfall, or it can be conducted under controlled conditions in industrial applications [45]. Results of elemental composition and ash fusibility show that leaching can result in significant improvements in combustion characteristics of straw and other biomass. Bench-scale combustion in an atmospheric fluidized bed combustor confirms that the extensive bed agglomeration that occurs with combustion of untreated rice straw does not take place with leached rice straw at combustion temperatures 
up to $900{ }^{\circ} \mathrm{C}$. In addition, blending leached rice straw into a woodbased fuel blend does not increase but rather leads to a decline in ash deposit formation rate. The mechanism for a decline in deposition rate is not fully understood but may be related to the increased loading rate of ash in the furnace and possibly higher erosion rates of deposits that do form [45].

Results obtained by Dayton et al. clearly indicate that leaching biomass effectively reduces or eliminates the release of alkali metal vapours during combustion. Leached and unleached samples of rice straw, wheat straw, switchgrass, wood fuel, sugarcane bagasse and banagrass (Pennisetum purpureum) were tested in bench-scale combustion studies using an alumina- tube flow reactor housed in a variable temperature furnace and coupled to a molecular beam mass spectrometer system. Total relative amounts of $\mathrm{HCl}(\mathrm{g}), \mathrm{SO} 2(\mathrm{~g}), \mathrm{NaCl}(\mathrm{g}), \mathrm{KCl}(\mathrm{g})$, and other inorganic constituents were compared for leached and unleached samples [46].

High calorific value easy-to-ignite coke-like biomass fuel briquettes can be manufactured from rice straw mixed with cattle manure, sawdust and other wastes and biomass material. Different processes have been suggested for the treatment of the biomass mixture.

In one process, the biomass mixture is pulverized, fermented at $30^{\circ} \mathrm{C}$ and preheated at $200-250{ }^{\circ} \mathrm{C}$ for $20 \mathrm{~min}$ to remove part of the volatile components and increase viscosity. The volatile components are collected and treated to generate fuel gas and tar, and the preheated biomass raw materials are compressed to obtain biomass fuel briquette. The obtained fuel briquette has a high density, long burning time and low ash content [47]. In another process, the biomass mixture, after pulverization and extrusion, is oven dried and carbonized at $600-800{ }^{\circ} \mathrm{C}$ for 10 $11 \mathrm{~h}$ [48]. In a third process, the straw is pulverized, dried at 150 ${ }^{\circ} \mathrm{C}$, mixed with other raw materials, press formed at $200{ }^{\circ} \mathrm{C}$, and finally carbonized at $300-350{ }^{\circ} \mathrm{C}[49]$. In experiments conducted by Lee et al. The optimum reaction temperature range for the production of bio-oil by fast pyrolysis was found to be 410-510 ${ }^{\circ} \mathrm{C}[50]$.

Alternatively, straw charcoal (with carbon content 30-35\%) can be manufactured from straws and other crop and wood wastes by incomplete gasification. The straw-derived charcoal is rich in nutrients for crops, and can be used as adsorbent for contaminated soil remediation [22]. Activated charcoal (typically obtained from rice straw) may also be gasified in an enclosed chamber with a limited amount of oxidant for generating fuel gas composed mainly of carbon monoxide and hydrocarbons [51]. Experimental results show that the gasification reactivity of rice straw char increases with decreasing pyrolysis temperature and increasing heating rate [52].

\section{Conclusion}

Rice straw is an abundant agricultural by-product of low commercial value which is available in large quantities. If utilized efficiently, rice straw can provide appropriate feedstocks for competitive bio-energy production.

Rice straw is an attractive lignocellulosic material that can be used for the production of liquid or gaseous fuel oils. It is particularly suited for bio ethanol production for it has several characteristics, such as high cellulose and hemicelluloses content that can be readily hydrolyzed into fermentable sugars. Through liquid fermentation other compounds may be produced from rice straw such as butanediol glycol.

Biogas or methane may be also produced from rice straw by fermentation or other gasification processes. In addition, rice straw may also be considered for the production of bio hydrogen, where the straw is converted to bio-oil by fast pyrolysis and the bio-oil steam reformed for the production of hydrogen. Using microwave-induced pyrolysis a hydrogen-rich fuel gas may be made from rice straw.

Furthermore, rice straw can be made into a solid fuel that can be fired with coal and natural gas either directly in the form of pales or pellets or after torrefaction or other processing. Mixed with other agricultural wastes, rice straw may also be made into a coke-like biomass fuel briquette. Finally, rice straw may be utilized for energy production in a high efficiency low cost microbiological fuel cell.

\section{References}

1. Ryou JG (2001) Water treatment equipment using rice straw; Korea Patent No. KR 2001087859, Korea.

2. Dominguez-Escriba L, Porcar M (2010) Rice straw management: the big waste. Biofuels, Bioproducts \& Biorefining 4(2): 154-159.

3. Binod P, Sindhu R, Singhania RR, Vikram S, Devi L, et al. (2010) Bioethanol production from rice straw: An overview. bioresour technol 101(13): 4767-4774.

4. Tokuyasu T, Park J, Arakane M (2010) Efficient saccharification of rice straw for ethanol manufacture. Japan Patent No. JP 2010035431, Japan.

5. Zhang B, Song A (2007) Fermentation method for producing fuel ethanol from straw. China Patent No. CN 101085994, China.

6. Wang K, Xiong X (2007) Method for producing ethanol from straw of rice, corn or sorghum. China Patent No. CN 101041834, China.

7. Al-Haj Ibrahim H (2012) Pretreatment of straw for bioethanol production. Energy Procedia 14: 542-551.

8. Vlasenko EY, Ding H, Labavitch JM, Shoemaker SP (1997) Enzymic hydrolysis of pretreated rice straw. Bioresource Technology 59(2-3): 109-119.

9. Zhang Y, Sun Y, He L, Li Y (2008) Production of fuel ethanol through liquefying straws. China Patent No. CN 101298744, China.

10. Zhang B, Song A (2006) Method for manufacturing ethanol fuel from straw fibers. China Patent No. CN 1880416, China.

11. Tokuyasu T, Kondo M (2009) Non-chemical saccharification of rice straw for making bioethanol. Japan Patent No. JP 2008-4393, Japan.

12. Silva JPA, Mussatto SI, Roberto IC (2010) The influence of initial xylose concentration, agitation, and aeration on ethanol production by Pichia stipitis from rice straw hemicellulosic hydrolysate. Appl Biochem Biotechnol 162(5): 1306-1315. 
13. Huang C, Lin T, Guo G, Hwang W (2009) Enhanced ethanol production by fermentation of rice straw hydrolysate without detoxification using a newly adapted strain of Pichia stipitis. Bioresour Technol 100(17): 3914-3920.

14. Zhang Y, He L, Yang Y (2009) Method for producing 2,3-butanediol used as clean fuel from straws through liquid fermentation. China Patent No. CN 101586127, China.

15. Li H, Yuan X, Zeng G, Tong J, Yan Y, et al. (2009) Liquefaction of rice straw in sub- and supercritical 1,4-dioxane-water mixture. Fuel Processing Technology 90(5): 657-663.

16. Li H, Yuan X, Zeng G, Tong J, Xie W, et al. (2008) Effect of mixed solvent on the sub- and supercritical liquefaction of agricultural waste. Nongye Gongcheng Xuebao 24(5): 200-203.

17. Chang J, Chou C, Ho C, Chen W, Lay J, et al. (2008) Syntrophic coculture of aerobic Bacillus and anaerobic Clostridium for bio-fuels and bio-hydrogen production. International Journal of Hydrogen Energy 33(19): 5137-5146.

18. Lei Z, Chen J, Zhang Z, Sugiura N (2010) Methane production from rice straw with acclimated anaerobic sludge: Effect of phosphate supplementation. Bioresource Technology 101(12): 4343-4348.

19. Zhang R, Zhang Z (1999) Biogasification of rice straw with an anaerobic-phased solids digester system. Bioresource Technology 68(3): 235-245.

20. He Y, Pang Y, Li X, Liu Y, Li R, et al. (2009) Investigation on the changes of main compositions and extractives of rice straw pretreated with sodium hydroxide for biogas production. Energy \& Fuels 23(4): 22202224 .

21. He Y, Pang Y, Liu Y, Li X, Wang K, et al. (2008) Physicochemical Characterization of Rice Straw Pretreated with Sodium Hydroxide in the Solid State for Enhancing Biogas Production. Energy \& Fuels 22(4): 2775-2781.

22. Li X, Xiao Y, Pang Y, Liu Y, Liu X, et al. (2008) Method and apparatus for producing clean vehicle fuel from crop straws. China Patent No. CN 101220292, China

23. Zhang Q Zhou J, Yi S, Song B (2008) Simultaneous manufacture of charcoal, fuel gas, and pyroligneous liquors by gasification of biomass and wood waste. China Patent No. CN 101186833, China.

24. Han L, Zhang L (2005) Fuel gas and charcoal briquet manufacture from agricultural wastes and forestry wastes. China Patent No. CN 1710022, China.

25. Fu P, Hu S, Xiang J, Sun L, Yang T, et al. (2009) Mechanism study of rice straw pyrolysis by Fourier transform infrared technique. Chinese Journal of Chemical Engineering 17(3): 522-529.

26. Wang M, Yang Y (2006) Method for producing liquefied fuel gas from plant straw, husk and bran. China Patent No. CN 1858157, China.

27. Chen Y, Luo Y, Wu W, Su Z (2009) Experimental investigation on tar formation and destruction in a lab-scale two-stage reactor. Energy \& Fuels 23(9): 4659-4667.

28. Huang YF, Kuan WH, Lo SL, Lin CF (2010) Hydrogen-rich fuel gas from rice straw via microwave-induced pyrolysis. Bioresource Technology 101(6): 1968-1973.

29. Huang YF, Kuan WH, Lo SL, Lin CF (2008) Total recovery of resources and energy from rice straw using microwave-induced pyrolysis. Bioresource Technology 99(17): 8252-8258.

30. Bai H, Sun Q Zhou P, Zhang C, Gu S, et al. (2009) Effect of alkali treatment on straw forming technology. Nongye Jixie Xuebao 40(3): 121-124.

31. Sato H (2010) Rice straw pellets and livestock feed containing the pellets and apple pomace. Japan Patent No. JP 2010130906, Japan.
32. Chou C, Lin S, Lu W (2009) Preparation and characterization of solid biomass fuel made from rice straw and rice bran. Fuel Processing Technology 90(7-8): 980-987.

33. Chou C, Lin S, Peng C, Lu W (2009) The optimum conditions for preparing solid fuel briquette of rice straw by a piston-mold process using the Taguchi method. Fuel Processing Technology 90(7-8): 10411046

34. Otake S, Taya A, Ishii N, Ochi E, Sugita S, et al. (1998) Solid fuel production and energy conversion for pollution control. Japan Patent No. JP 10001685, Japan.

35. Kang Z (2010) Method for manufacturing compressed fuel rods. China Patent No. CN 101676370, China.

36. Zhang B, Li B, Fan F, Yang S (2007) Method for producing rod-shaped compact straw fuel. China Patent No. CN 101139538, China.

37. Chen W (2010) Environmentally-friendly solid fuel and its preparation from crop waste. China Patent No. CN 101798541, China.

38. Chen WC (2010) Method of transforming a crop waste into a solid fuel and a solid fuel made by the method. USA Patent No. US 20100199550 USA.

39. Liu H, Feng Y, Wu S, Liu D (2009) The role of ash particles in the bed agglomeration during the fluidized bed combustion of rice straw. Bioresource Technology 100(24): 6505-6513.

40. Lu X, Yu Y, Lin P, Luo Y, Duan J, et al. (2009) Grate firing characteristics of typical biomass fuels. Dongli Gongcheng 29(3): 282-286.

41. Thy P, Jenkins BM, Williams RB, Lesher CE, Bakker RR, et al. (2010) Bed agglomeration in fluidized combustor fueled by wood and rice straw blends. Fuel Processing Technology 91(11): 1464-1485.

42. Oh DG (2010) Method for manufacturing solid fuel from rice straw. Korea Patent No. KR 2010022948, Korea.

43. Tian Y, Zhao L, Meng H, Yao Z, Sun L, et al. (2010) Antislagging additive for biomass solid fuel briquet and its preparation method, China Patent No. CN 101775324, China.

44. Yuan S, Yuan Y, Peng C (2009) Swirling-flow air distribution apparatus for biomass fluidized bed. China Patent No. CN 101571288, China.

45. Bakker RR, Jenkins BM, Williams RB (2002) Fluidized Bed Combustion of Leached Rice Straw. Energy \& Fuels 16(2): 356-365.

46. Dayton DC, Jenkins BM, Turn SQ, Bakker RR, Williams RB, et al. (1999) Release of Inorganic Constituents from Leached Biomass during Thermal Conversion. Energy \& Fuels 13(4): 860-870.

47. Zheng W (2010) Method for manufacturing coke-like biomass fue briquette. China Patent No. CN 101629115, China.

48. Xuping S (2010) Method for manufacturing solid fuel from cattle manure, straw, and sawdust. China Patent No. CN 101629114, China.

49. Zhang L, Wang G (2004) Method for preparation of solid fuel briquets from straw. China Patent No. CN 1699525, China.

50. Lee K, Kang B, Park Y, Kim J (2005) Influence of Reaction Temperature, Pretreatment, and a Char Removal System on the Production of Biooil from Rice Straw by Fast Pyrolysis, Using a Fluidized Bed. Energy \& Fuels 19(5): 2179-2184.

51. Hanyuan T (2007) Furnace for generating coal gas from charcoal. China Patent No. CN 101037619, China.

52. Huang Y, Yin X, Wu C, Wang C, Xie J, et al. (2009) Study on $\mathrm{CO}_{2}$ gasification reactivity of rice straw chars. Ranliao Huaxue Xuebao 37(3): 289-295 
This work is licensed under Creative Commons Attribution 4.0 License

DOI: 10.19080/RAPSCI.2018.05.555671

\section{Your next submission with Juniper Publishers} will reach you the below assets

- Quality Editorial service

- Swift Peer Review

- Reprints availability

- E-prints Service

- Manuscript Podcast for convenient understanding

- Global attainment for your research

- Manuscript accessibility in different formats ( Pdf, E-pub, Full Text, Audio)

- Unceasing customer service

Track the below URL for one-step submission https://juniperpublishers.com/online-submission.php 